\title{
HISTOCHEMICAL STUDY OF THE SKELETAL MUSCLE IN CHILDREN WITH CHRONIC RENAL FAILURE IN DIALYSIS TREATMENT
}

\author{
LUCILA BIZARI FERNANDES DO PRADO*, GILMAR FERNANDES DO PRADO**, \\ ACARY SOUZA BULLE OLIVEIRA***, BENY SCHMIDT****, \\ JOÃO TOMÁS DE ABREU CARVALHAES ${ }^{* * * *}$
}

\begin{abstract}
Among the modifications occurring in the uremic organism, in addition to the consequences of dialysis, myophathy and peripheral neuropathy are very significant. Children are particularly affected, as their growth and development are jeopardized. Histochemistry of muscular biopsy was used to study eighteen children with end-stage renal failure under dialysis during a ten-month period. According to our results, the skeletal muscular tissue presented the following types of alterations: atrophy, type grouping, lipidosis, glycogen depletion and mitochondrial proliferation.
\end{abstract}

KEY WORDS: chronic renal failure, dialysis, muscular biopsy, uremia.

\section{Estudo histoquímico do músculo esquelético em crianças com insuficiência renal crônica em tratamento dialítico}

RESUMO - Dentre as modificações que o organismo urêmico sofre, acrescido das consequências do tratamento dialítico, miopatia e neuropatia periférica são de real importância. A criança é particularmente afetada, pois seu crescimento e desenvolvimento estão comprometidos. Foram estudadas dezoito crianças com insuficiência renal crônica terminal em programa de diálise, num período de dez meses, através da histoquímica da biópsia muscular. Segundo nossos resultados, o tecido muscular esquelético apresentou alterações tipo atrofia, type grouping, lipidose, depleção de glicogênio e proliferação mitocondrial.

PALAVRAS-CHAVE: insuficiência renal crônica, diálise, biópsia muscular, uremia.

The uremic child is severely ill since one of the uremic characteristics is the deep alteration of the cell energetic metabolism ${ }^{1,2}$. Nitrogen retention which affects ions transportation and cell metabolism, that is, biochemical changes (which include damage in the energy use, abnormal catabolism of carbohydrates, fat and proteins) reflect in the organism as endocrinous disorders, anemia, delay in growth, malnutrition, osteodystrophy, cardiovascular alterations and neurologic disorders ${ }^{2,3}$.

Peripheral neuropathy in patients with chronic renal failure has been known since XIX century. Kussmaul, in 1864, described adipose degeneration of the myelin sheath in the sciatic nerve of uremic patients with paresis of the lower limbs ${ }^{4}$. Histological studies showed destruction of myelin and axons, predominantly in distal segments of the peripheric nerves ${ }^{5-10}$.

Departamento de Pediatria da Escola Paulista de Medicina - Universidade Federal de São Paulo (EPMUNIFESP), São Paulo, Brasil: *Mestre em Nefrologia; **Professor Doutor da Disciplina de Clínica Médica; ***Professor Doutor e Chefe do Setor de Doenças Neuromusculares da Disciplina de Neurologia; ****Professor Adjunto Doutor da Disciplina de Anatomia Patológica; *****Professor Doutor e Chefe do Setor de Nefrologia Pediátrica do Departamento de Pediatria. Aceite: 25-abril-1998.

Dr. Gilmar Fernandes do Prado - Rua Cláudio Rossi 404 - 01547-050 São Paulo SP - Brasil. E-mail: gilmar.dmed.@epm.br 
Specific myopathy of uremia, non related to polineuropathy, has been reported in histochemical and ultrastructural studies of the skeletal muscle in adults. Thus, in addition to the preferential atrophy of type II muscle fibers, secondary to the neural damage, the following characteristics of the abnormal cytoarchitecture to the coexistent non-neural damage can happen: focal disorganization of the myofibrillar standard (appearance of moth-eaten fibers of type I fibers), decrease in the amount of mitochondria, lysosome aggregation in the border of the cell, fragments of myofribils and disorganization of material in the $\mathrm{Z}$ line. However, frank characteristics of myopathy, that is, necrosis and phagocytosis of fibers are not usually present ${ }^{11}$.

Lancelotti et al. ${ }^{12}$ studying the skeletal muscle in undernourished adults observed neurogenic amyothrophy of varied degrees: presence of atrophic angular type II fibers and nuclear sacs with varied degrees of intensity lesion in addition to the cases with type grouping, that is, alteration of the normal mosaic characterized as groupings with only one type of fiber, I or II.

Children's organism with chronic renal failure (CRF) is still growing and developing, and dialysis only minimizes the severe defects of uremia while they wait for the transplantation. Although treated with several types of dialysis procedures, the children still present neuromuscular structural alterations which have been scarcely appreciated in the literature. The present study has the objective to show the alterations in which the skeletal muscle of the children, submitted to different dialysis treatment, suffers when facing a severe condition as that of CRF.

\section{MATERIAL AND METHODS}

This study was approved by the committee of ethics (Comissão de Ética Médica, EPM-UNIFESP). Parents had all information about it, and the children's inclusion was conditioned to parents' agreement, formalized by a Committee document subscription.

Eighteen children with end-stage CRF in a dialysis program, followed-up in the Sector of Pediatric Neurology of the Department of Pediatrics - UNIFESP-EPM, in a 10 month period were studied. Nine were female and nine male; ages ranged from 3 to 173 months (mean age 104 months old); diagnosis were listed (Table 1).

The dialysis program varied according to access route, availability and parents' training: hemodialysis, intermittent peritoneal dialysis and continuous ambulatorial peritoneal dialysis (CAPD). Time of dialysis varied from 3 to 34 months.

Biopsy of the deltoid muscle was performed (contralateral to the arteriovenous fistula, when present) according to the methodology proclaimed by Dubowitz ${ }^{13,14}$ using the technique of "farabeufs' dance" of Schmidt ${ }^{15}$. After fixation and incision, muscle fragments were submitted to histological staining using methods of hematoxylin-eosin, modified Gomori trichrome and Sudan red. Histochemical reactions carried out were: nicotinamide dehydrogenase tetrazolium-reductase (NADH), succinate dehydrogenase (SDH), alphaglycerolphosphate-dehydrogenase (alpha-GPD), periodic acid Schiff (PAS), adenosine-triphosphatase (ATPase) with preincubation at different $\mathrm{pHs}(\mathrm{pH} \mathrm{4.35,4.63}$ and 9.40).

Microscopic analysis aimed to observe the presence or absence of atrophy of muscular fibers, which resulted of a process in which there is an elongation and a triangular aspect of the muscle fibers, occurring selectively in type II fibers (anaerobic fibers). This is one of the most frequent abnormalities of the muscle, and is observed in several neurological diseases and in situations of muscle disuse as extended rest ${ }^{11}$. Its occurrence indicates inactivity of the muscle and not the cause. Atrophy degree was expressed in,+++ or +++ according to its intensity: slight, moderate or severe, respectively. It may be assessed in the muscle biopsy through hematoxilineosin staining and histochemical reactions with alpha-GPD, ATPase in the already mentioned pHs.

The lipid droplets usually found in small number in the sarcoplasm and with uniform distribution. When they present a gross aspect and are found in a great number, they characterize a picture that we have called muscular lipidosis. This was measured in crosses (from + to +++ ) according to appearance degree. Sudan red staining was used to measure adipose droplets.

PAS staining was used to detect intrasarcoplasmatic glycogen deposit with the objective to verify the presence or absence of glycogen depletion.

Oxidative staining (SDH and modified Gomori trichrome) were used to detect abnormalities such as mitochondria proliferation, which suggests altered cell energetic metabolism. The proliferation was classified as present or absent and, when present was classified in crosses from + to +++ according to the appearance degree. 
Table 1. Sex, age in years and months, dialysis treatment, time of dialysis $(t d)$ and nephrology diagnosis.

\begin{tabular}{cccccccl}
\hline Case & Patient & Sex & Age $_{1}$ & Age $_{2}$ & Method & TD & Diagnosis \\
\hline 1 & SAR & F & 13 & 163 & HD & 34 & Reflux nephropathy \\
2 & EFC & M & 9 & 108 & HD & 17 & Reflux nephropathy \\
3 & IAP & F & 8 & 99 & HD & 12 & Renal malformation \\
4 & ARS & M & 8 & 107 & HD & 13 & Nephronophthisis \\
5 & SB & F & 3 & 36 & IPD & 7 & Hemolytic-uremic syndrome \\
6 & EAOS & F & 5 & 71 & IPD & 5 & Glomerulonephritis (GN) \\
7 & DCSM & M & 0 & 3 & IPD & 2 & Valve of the posterior urethra \\
8 & MRSP & F & 11 & 135 & IPD & 8 & Lupus nephritis \\
9 & RRS & M & 9 & 117 & CAPD & 8 & Valve of the posterior urethra \\
10 & GSG & F & 14 & 173 & CAPD & 23 & Glomerulonephritis (GN) \\
11 & VS & F & 12 & 151 & CAPD & 28 & Oxalosis \\
12 & LCRP & M & 8 & 100 & CAPD & 31 & Segmental and focal GN \\
13 & FLB & M & 3 & 41 & CAPD & 17 & Valve of the posterior urethra \\
14 & MAL & M & 9 & 119 & CAPD & 13 & Glomerulonephritis (GN) \\
15 & ES & F & 13 & 163 & CAPD & 11 & Renal malformation \\
16 & EDS & F & 6 & 75 & CAPD & 7 & Reflux nephropathy \\
17 & MJC & M & 10 & 124 & CAPD & 13 & Glomerulonephritis (GN) \\
18 & WFD & M & 6 & 80 & CAPD & 3 & Cystinosis \\
\hline
\end{tabular}

HD, hemodialysis; IPD, intermittent peritoneal dialysis; CAPD, continuous ambulatorial peritoneal dialysis; F, female; M, male; ; years; ${ }_{2}$, months.

\section{RESULTS}

All patients presented atrophy of the muscle cells which selectively impaired type II fibers in 15 patients and in three patients it was non-selective (Table 2). Type grouping occurred in twelve patients (Fig 1).

All patients presented muscular lipidosis (Fig 1). It was accentuated in four patients, moderate in four and slight in ten.

Only five patients did not present glycogen depletion.

Eleven patients presented accentuated mitochondria proliferation (Fig 1); it was moderate in three and accentuated in two. Mitochondria proliferation was not observed only in two patients. The mitochondria proliferation pattern was diffuse and predominated in the subsarcolemma.

\section{DISCUSSION}

In a great or small degree of severity, atrophy of the muscle fibers was present in all biopsies of our cases, and muscle weakness and exhaustion to physical exercises were observed in these patients ${ }^{11,16-19}$. Both patients and uremic animals are hypercatabolics, and in this process there is an involvement of the skeletal muscle which is a target tissue for catabolism and also for abnormal 


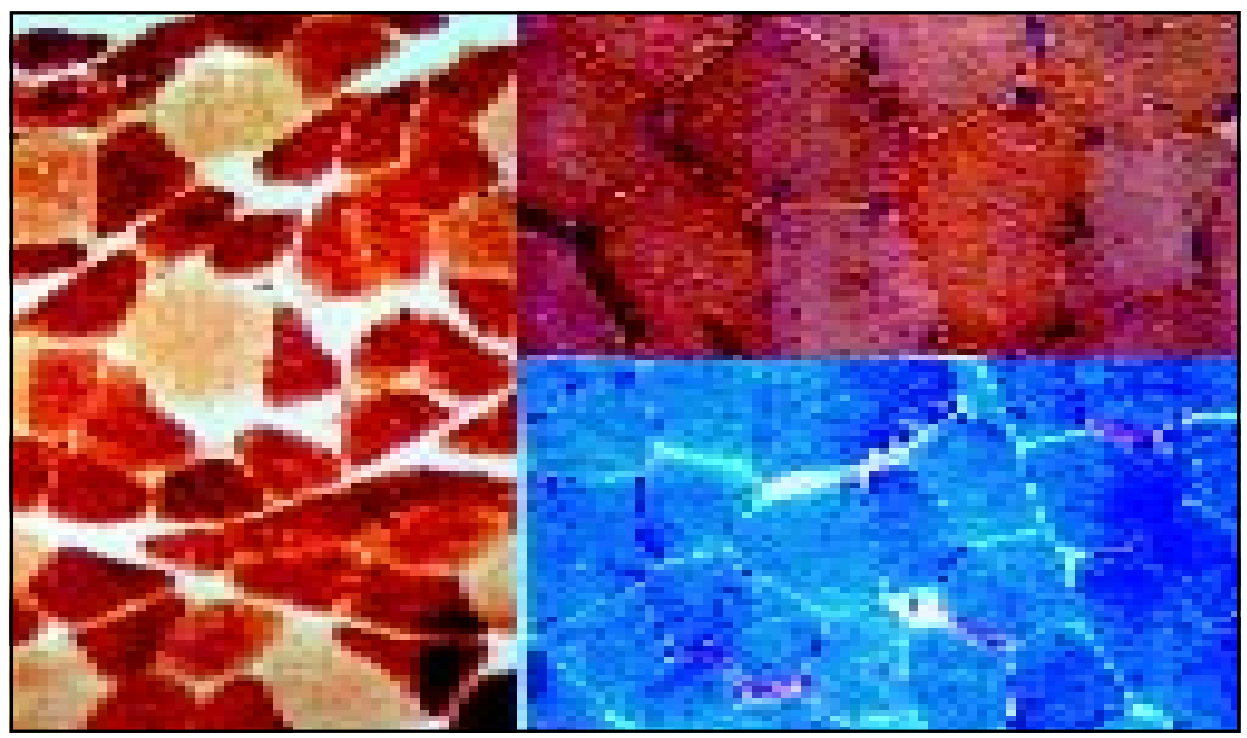

Fig 1. Left: Type grouping (ATPase, pH 9.40 x 350). Rigth superior: Muscular lipidosis (Sudan red x 500). Rigth inferior: Mitochondrial proliferation (Gomori trichrome x 350).

metabolism of the hormones (metabolites of vitamin D, PTH, insulin and catecholamines) associated with the so-called uremic myopathy ${ }^{17,18,20-23}$.

The atrophy of type II muscle fibers which was predominant in our findings may be present in neuropathic processes, that is, secondary atrophy to neural damage ${ }^{22}$. However, the skeletal muscle can develop alterations independent of the processes which primarily affect the nerve ${ }^{16}$, called myogenic myopathy ${ }^{21}$, mainly affecting type II fibers which is also observed in patients with primary hyperparathyroidism ${ }^{24,25}$.

Neurogenic or myogenic atrophy of the muscle fibers which, under microscopic point of view, occurs in all the muscle groups is considered a severe inconvenience to children, in addition to the fact of being under growth and development curve. Children, even in dialysis treatment, present alterations that can be summarized in a clinical evaluation as malnutrition. This is a severe disease that when observed in uremic children may present muscle trophic alterations due to severe metabolic changes which probably are independent of the nutrient offer. If our objective was to offer ideal conditions of growth and development to children, certainly dialysis is not fulfilling this condition. Differing from the adults who had already reached or had the chance to reach their capacities, the child, in addition to have the same losses and experienced the same suffering and molestation of the dialysis treatment, present an incommensurable difficulty to plentifully grow and develop their potentials. If our efforts could be orientated, they must be in this way, to guarantee a better treatment for chronic renal failure than that of dialysis.

Type grouping, indicative of amyothrophy process of neurogenic origin, was present in twelve (66.67\%) patients and could be considered as a secondary alteration to peripheral neuropathy ${ }^{11,26}$, usually an end-stage complication of renal failure ${ }^{6,20,27}$.

Skeletal muscle fibers are innervated by neurons from the anterior horn of the spinal cord and are classified in type I, IIa, IIb and IIc, according to the type of neurons which stimulate them. Thus, the normal skeletal muscle presents alternations of type I and type II fibers, presenting a "mosaic" shape when transversally cut and observed by histochemical staining. When neuron is damaged, all muscle fibers innervated by it, lose their trophic stimulus, atrophying and acquiring an angular 
Table 2. Main findings of the muscle biopsy.

\begin{tabular}{|c|c|c|c|c|c|}
\hline Case & $\begin{array}{c}\text { Muscle } \\
\text { fibers atrophy }\end{array}$ & $\begin{array}{c}\text { Type } \\
\text { grouping }\end{array}$ & $\begin{array}{c}\text { Muscle } \\
\text { lipidosis }\end{array}$ & $\begin{array}{l}\text { Muscle glycogen } \\
\text { depletion }\end{array}$ & $\begin{array}{r}\text { Mitochondria } \\
\text { proliferation }\end{array}$ \\
\hline 1 & ++ & Present & + & Present & + \\
\hline 2 & +++ & Present & + & Present & + \\
\hline 3 & + & Present & ++ & Absent & ++ \\
\hline 4 & ++ & Present & + & Present & + \\
\hline 5 & + & Present & +++ & Present & +++ \\
\hline 6 & ++ & Present & ++ & Absent & Absent \\
\hline 7 & ++ & Absent & + & Absent & Absent \\
\hline 8 & +++ & Absent & + & Absent & + \\
\hline 9 & + & Absent & + & Present & + \\
\hline 10 & + & Present & + & Present & + \\
\hline 11 & + & Present & ++ & Present & ++ \\
\hline 12 & $+*$ & Absent & + & Present & + \\
\hline 13 & $+++*$ & Absent & ++ & Present & + \\
\hline 14 & $+^{*}$ & Absent & + & Present & + \\
\hline 15 & ++ & Present & +++ & Present & +++ \\
\hline 16 & ++ & Present & +++ & Present & ++ \\
\hline 17 & ++ & Present & + & Absent & + \\
\hline 18 & +++ & Present & +++ & Present & + \\
\hline
\end{tabular}

+, slight; ++, moderate; +++, accentuate; *, non-selective atrophy of the fibers.

aspect which characterizes the denervation process. The neighboring neurones which did not suffer lesions, by budding (sprouting), emit elongations up to atrophied fibers which acquire a new energetic metabolism, and histochemical reactions similar to the neighboring fibers. Thus, type grouping - a group of muscle fibers of the same histochemical type - explain the process of reinnervation preceded by denervation, that is, neurogenic amyothrophy. Type grouping is a pathognomonic alteration of a neurogenic process characterized by denervertion and renervation. In our sample we had $12(66.67 \%)$ type grouping, that is, most of our children presented direct or only partial involvement of the peripheric nerve. This finding adds more evidence to the severe disorder that children under dialysis procedure are submitted.

It is known that uremia elicits severe alterations in the nervous system, leading to coma inclusively. Nevertheless, when under dialysis procedures these severe disorders remain controlled and it is difficult to foresee the hidden effects of the metabolic abnormality on the nervous system. Our findings allow us to say that these alterations continue occurring although the patient apparently, in particular the child, does not account for it.

Muscular lipidosis was also present in many degrees of intensity in all biopsy findings, probably reflecting one more energetic metabolic abnormality in the uremic child, adding, once more, deleteric 
elements to the infantile organism. Generally, intrasarcoplasmatic lipid droplets exist in small quantities and are uniformly distributed. When they present a gross aspect and occur in great number, they indicate the presence of mithocondriopathies in addition to some muscle atrophies and carnitine deficit. Lipidic intracellular droplets may be related to muscle deficiency of carnitine once excluded muscle dystrophies and mithocondriopathies ${ }^{11,19,28}$. Carnitine deficit elicits the accumulation of lipid in the cytoplasm (myopathy of lipid storage), which can be evidenced at the muscle histochemistry ${ }^{28-30}$.

Sixteen cases of mitochondria proliferation $(88.89 \%)$ in diverse degrees of intensity were observed. Mitochondria proliferation may suggest a metabolic adaptation because this proliferation is a response to the adverse conditions that renal chronic organism confronts, clearly depletion of carnitine which is also responsible by lipidosis ${ }^{11,31-33}$. In our cases, mitochondria proliferation was more intense when great lipid accumulation was observed.

Glycogen depletion was observed in thirteen studied children (72.22\%). Absence of glycogen may be associated with the initial phases of denervation ${ }^{34}$.

Alterations observed in a muscle biopsy of the child are similar to that of the adult ${ }^{11,35}$ reflecting, as already mentioned, severe metabolic modifications in the uremic organism. However, consequences of such conditions in children are most harmful since affect particularly their growth and development. The choice for dialysis and/or nutrients and vitamin replacement may minimize these alterations while waiting for renal transplantation, which is the final objective for the patient with chronic renal failure and specially for the child who might as well find metabolic conditions adequate to needs and thus being able to thoroughly grow and develop, with a chance to expand his/her capacities.

Few attention has been given to this type of alteration in uremic children and there is a need to extend this type of research by increasing the number of cases for each specific type of dialysis used in the treatment with the objective to minimize the effects above characterized.

The results also suggest the need of experimenting some therapeutic effect of the carnitine that if concomitantly used in dialysis may improve the metabolism, collaborating to reduce nutritional alterations in uremic children. In brief, the physician must be observing the whole rank of detectable alterations, aiming a global treatment specially directed to an adequate growth and development of the child, which is the objective not only of physicians and parents, but of the whole society.

\section{REFERENCES}

1. Del Canale S, Fiaccadori E, Ronda N, Söderlund K, Antonucci C, Guariglia A. Muscle energy metabolism in uremia. Clin Exp 1986;35:981-983.

2. Mujais SK, Sabatini S, Kurtzman NA. Pathophysiology of the uremic syndrome. In Brenner BM, Rector FC (eds). The kidney. 3.Ed. Philadelphia: W.B. Saunders 1986:1587-1630.

3. Papadopoulou ZL. Chronic renal failure. In Barakat AY. Renal disease in children. New York: Springer-Verlag 1990:285-306.

4. Nielsen VK. The peripherical neuropathy in patients with chronic renal failure. Acta Med Scand 1974;573(Suppl.):7-32.

5. Versaci AA, Olsen KJ, McMain PB, Nakamoto, Kolff WJ. Uremic polyneuropathy and motor nerve conduction velocities. Trans Am Soc Artif Int Org 1964;10:328-330.

6. Jebsen RH, Tenckhoff H, Honet JC. Natural history of uremic polyneuropathy and effects of dialysis. N Engl J Med 1967;277:327-333.

7. Dick PJ, Johnson J, Lambert EH, O'Brien PC. Segmental demyelination secondary to axonal degeneration in uremic neuropathy. Mayo Clin Proc 1971;46:400-431.

8. Kjellstrand CM, Petersen RJ, Evans RL, Shildeman JR, Von Hartitzsch B, Buselmeter TJ. Considerations of the middle molecule hypotesis: II. Neuropathy in nephrectomized patients. Trans Am Soc Artif Int Org 1973;19:325-336.

9. Nielsen VK. The peripherical nerve function in chronic renal failure: VII. Longitudinal course during terminal renal failure and regular hemodialysis. Acta Med Scand 1974;195:155-162.

10. Albetrtazzi A, Cappelli P, Di Marco T, Maccarone M, Di Paolo B. The natural history of uremic neuropathy. Contr Nephrol 1988;65:130-137.

11. Machado CE. Valor da biópsia muscular associada a técnicas histoquímicas de coloração no diagnóstico da etiologia da fraqueza muscular em pacientes renais submetidos a programa de diálise crônica. Tese de Mestrado, Escola Paulista de Medicina. São Paulo, 1987.

12. Lancellotti CLP, Ponzoni ME, Schmidt B, Rasslan S. Estudo histoquímico da musculatura esquelética em doentes desnutridos. Rev Paul Med 1988;106:190-196. 
13. Dubowitz V, Brooke MH. Muscle biopsy: a modern approach. London: W.B. Saunders 1973.

14. Dubowitz V. Muscle biopsy: a pratical approach. 2.Ed. London: Baillière Tindall, 1986.

15. Schmidt B, Gabbai AA, Oliveira ASB, Braga MB Jr, Castello A Filho, Laredo J Filho. Biópsia muscular, nova metodologia: a dança dos "farabeufs". Rev Bras Ortop 1988;23:21-26.

16. Isacs H. Eletromyographic study of muscular weakness in chronic renal failure. S Afr Med J 1969;43:683-688.

17. Ritz E, Boland R, Kreusser W. Effects of vitamin D and parathyroid hormone on muscle: potential role in uremic myopathy. Am J Clin Nutr . 1980;33:1522-1529.

18. Bautista J, Gil-Necija E, Castilla J, Chinchon I, Rafael E. Dialysis myopathy. Acta Neuropathol (Berl) 1983;61:71-75.

19. Brautbar N. Skeletal myopathy in uremia: abnormal energy metabolism. Kidney Internat 1983;24(Suppl 16):S81-S86.

20. Jennekens FGI, Mees EJD, Van Spijk DM. Clinical aspects of uraemic polyneuropathy. Nephron 1971;8:416-426.

21. Floyd M, Ayyar DR, Barwick DD, Hudgson P, Weightman D. Myopathy in chronic renal failure. J Med 1974;43:509-524.

22. Ritz E, Kreusser W, Rambausek M, Mehls O. Myopathy of uremia. Adv Exp Med Biol 1984;178:371-386.

23. Tarasuk A, Heiner D, Bark $\mathrm{H}$. Effect of chronic renal failure on skeletal and diaphragmatic muscle contraction. Am Rev Resp Dis 1992;146:1383-1388.

24. Mallette LE, Patten BM, Engel WK. Neuromuscular disease in secondary hyperparathyroidism. Ann Intern Med 1995;82:474-483.

25. Lazaro RP, Kishner HS. Proximal muscle weakness in uremia. Arch Neurol 1980;37:555-558.

26. Morris CJ, Raybould JA. Fiber type grouping and end-plate diameter in human skeletal muscle. J Neurol Sci $1971 ; 13: 181-187$

27. Asbury WC, Victor M, Adams RD. Uremic polyneuropathy. Arch Neurol 1963;8:83-98.

28. Savica V, Bellinghiei G, Di Stefano C, et al. Plasma and muscle carnitine levels in haemodialysis patients with morphological ultrastructural examination of muscle samples. Nephron 1983;35:232-236.

29. Engel AG, Angelini C. Carnitine deficiency of human skeletal muscle with associated lipid storage myopaty: a new syndrome. Science 1973;179:899-901.

30. Jacob C, Belleville F. L-carnitine: metabolism, fonctions et interet en pathologie. Pathol Biol Paris 1992;40:910-919.

31. Kkan L, Bamji MS. Plasma carnitine levels in children with protein-calorie malnutrition before and after rehabilitation. Clin Chim Acta 1077;75:163-166.

32. Engel AG. Carnitine deficiency syndrome and lipid storage myopathies. In Engel AG, Banker B (eds). Myology: basic and clinical. New York: McGraw-Hill 1986:1663-1696.

33. Guarnieri G, Toigo G, Situlin R, Carraro M, Tamaro G. Carnitine metabolism in chronic renal failure. Contr Nephrol 1988;65:1-23.

34. Engel WK. Muscle target fibers, a newly recognized sign of denervation. Nature 1961;4786:389-390.

35. Prado LBF. Estudo histoquímico do músculo esquelético em crianças com insufiência renal crônica em tratamento dialítico. Tese de Mestrado, Escola Paulista de Medicina. São Paulo, 1992. 